Research Article

\title{
In-vitro evaluation of botanicals and fungicides against Bipolaris sorokiniana, causing spot blotch of wheat
}

\author{
Prem Bahadur Magar ${ }^{1 *}$, Suraj Baidya ${ }^{1}$, Rabina Koju ${ }^{2}$ and Sagar Adhikary ${ }^{3}$ \\ ${ }^{1}$ National Plant Pathology Research Centre (NPPRC), NARC, Khumaltar, Lalitpur, Nepal \\ ${ }^{2}$ Himalayan College of Agricultural Sciences and Technology, Purbanchal University, Kathmandu, \\ Nepal \\ ${ }^{3}$ Department of Plant Sciences, North Dakota State University, North Dakota, USA \\ *Correspondence: premmagar12@gmail.com \\ *ORCID: https://orcid.org/0000-0003-3263-1416 \\ Received: September 30, 2020; Accepted: October 25, 2020; Published: October 30, 2020
}

(C) Copyright: Magar et al. (2020).

(c) (1) T) This work is licensed under a Creative Commons Attribution-Non Commercial 4.0 International License.

\begin{abstract}
Spot blotch disease of wheat caused by Bipolaris sorokiniana; is one of the most concerning disease in warm and humid regions of Nepal due to its widespread prevalence and increasing severity. An in-vitro experiment was conducted to evaluate the efficacy of different botanicals and fungicides against $B$. sorokiniana, in National Plant Pathology Research Centre's laboratory at Khumaltar, Lalitpur in 2019. The experiment was done in completely randomized design with three replications by poison food technique. Five botanicals viz. neem, garlic, eucalyptus, bojho and asuro at three different concentrations $(5 \%, 10 \%$ and 15\%) and eight fungicides viz. sectin, curex, bavistin, vacomil plus, saaf, sajha, criptan and tilt at three concentration levels ( $25 \mathrm{ppm}, 50 \mathrm{ppm}$ and $100 \mathrm{ppm}$ ) except curex (50 ppm, $100 \mathrm{ppm}$ and $200 \mathrm{ppm}$ ) were used to evaluate the effect on the radial mycelial growth and mycelial growth inhibition percentage of the pathogen. The different botanical extracts and fungicides in different concentrations inhibited the mycelial growth of fungus significantly $(\mathrm{p}<0.01)$. The highest mycelial growth inhibition percentage was found by the application of garlic clove extract $(52.85 \%)$ at $15 \%$ which was followed by bojho $(52.48 \%)$ at $15 \%$ concentration. While tilt was found effective fungicide which completely inhibits the mycelial growth at all concentrations. Also, fungicides viz. sajha $(79.78 \%)$, saaf $(73.59 \%)$ and sectin $(70 \%)$, at $100 \mathrm{ppm}$ were found effective in controlling the pathogen as compare to others. Mycelial growth inhibition of the fungus was found to be increased with the increase in concentrations of botanicals and fungicides.
\end{abstract}

Keywords: B. sorokiniana, botanicals, fungicides, mycelial growth, poison food technique, wheat

Correct citation: Magar, P.B., Baidya, S., Koju, R., \& Adhikary, S. (2020). In vitro evaluation of botanicals and fungicides against Bipolaris sorokiniana, causing spot blotch of wheat. Journal of Agriculture and Natural Resources, 3(2), 296-305.

DOI: https://doi.org/10.3126/janr.v3i2.32534

\section{INTRODUCTION}

Wheat (Triticum aestivum L.) is third most important cereal crop of Nepal after rice and maize based on both area (703,992 ha) and production (2,005,665 tons) (MoALD, 2018/19). It is grown all over the country; however, plain areas are the main growing regions in Nepal. The lower yield of wheat is due to several biotic and abiotic factors such as disease, poor management practices, soil fertility status etc. (Ruckstuhl, 1997; Regmi et al., 2002). Among the biotic factors, diseases are the most important constraints of wheat production in Nepal. Helminthosporium leaf blight (HLB) also commonly called as foliar blight (FB), a complex of spot blotch (Bipolaris 
sorokiniana) and tan spot (Pyrenophora tritici repentis); disease of wheat is very severe in Terai areas. High temperature and high relative humidity favour the outbreak of the disease, in particular in South Asia's intensive 'irrigated wheat-rice' production systems (Kumar et al., 2002). However, the leaf blight disease has been increased in areas having moderate temperature and will be a problem in future for wheat growers of Kathmandu valley and similar mid-hills regions of Nepal (Bhandari, 2017). The disease occurs every year in warm wheat growing areas of Nepal in moderate to severe form (Duveiller et al., 2005). The losses due to spot blotch in warm regions of Nepal ranged from $23-40 \%$ depending on the genotypes and other environmental factors (Bhandari and Tripathi, 2005; Sharma and Duveiller, 2006).

A number of systemic fungicides with different modes of action and targets have been developed to reduce the losses caused by the disease (Pasquer et al., 2005). Use of chemical pesticides is the most frequent management practice but not always recommended due to environmental concern and health hazards. So, in search of alternative to chemicals, an ecofriendly and sustainable management option can be the use of different botanicals which have antifungal activity to the spot blotch pathogen. Very few works have done using botanical extracts and fungicides in the country to control spot blotch of wheat. It is important to examine the effect of different concentration of botanical extracts and different fungicides commonly available in market to control this disease. Hence, the study was undertaken to evaluate different botanical extracts and chemical fungicides for their efficacy against $B$. sorokinana under in vitro condition.

\section{MATERIALS AND METHODS}

\section{Experimental site and pure culture preparation of Bipolaris sorokiniana}

The experiment was conducted in the laboratory of National Plant Pathology Research Centre (NPPRC), Khumaltar, Lalitpur, Nepal. Samples of spot blotch disease were collected from wheat growing fields of Khumaltar during 2019. Diseased parts were cut into $1 \mathrm{~cm}$ pieces and sterilized with $1 \%$ sodium hypochlorite $(\mathrm{NaOCl})$ for 30 seconds which was then rinsed with distilled water for three times. Those cut pieces were dried under laminar flow and placed on water agar plates and incubated at $25^{\circ} \mathrm{C}$ for two days. Microscopic observation confirmed the presence of Bipolaris sorokiniana. Pathogen pure culture was performed on PDA plates under aseptic condition by taking single germinating spore in water agar. The plates were incubated at $25^{\circ} \mathrm{C}$ for 1 week until full growth obtained and pathogen sub culture done aseptically for further study.

\section{Preparation of Botanical extracts}

The botanicals used for the experiment were Neem (Azadirachta indica), Garlic (Allium sativum), Eucalyptus (Eucalyptus globolus), Bojho (Acorus calamus) and Asuro (Justicia adhatoda). The cloves of garlic, rhizome of bojho and leaves of neem, eucalyptus and asuro were used to prepare extract. All these five botanical extracts were used in 5\%, $10 \%$ and $15 \%$ concentration level. Extracts were prepared by grinding with the help of mixer grinder and mortar and pestle with equal amount of distilled water $(1: 1 \mathrm{wt} / \mathrm{vol})$. The extract then filtered through muslin cloth to get the stock solution of $100 \%$ concentration and sterilized by autoclaving at $110^{\circ} \mathrm{C}$ for 10 minutes.

\section{Fungicides}

Eight chemical fungicides viz. Sectin (Fenamidone 10\% + Mancozeb 50\%), Curex (Copper oxychloride 50\%), Bavistin (Carbendazim 50\%), Vacomil plus (Metalaxyl 15\% + Copper oxychloride 35\%), Sajha (Tebuconazole 10\% + Sulphur 35\%), SAAF (Carbendazim 12\% + 
Journal of Agriculture and Natural Resources (2020) 3(2): 296-305

ISSN: 2661-6270 (Print), ISSN: 2661-6289 (Online)

DOI: https://doi.org/10.3126/janr.v3i2.32534

Mancozeb 63\%), Criptan (Captan 50\%) and Tilt (Propiconazole 25\%) were selected for the experiment. They were used in three different concentration level i.e. $25 \mathrm{ppm}, 50 \mathrm{ppm}$ and 100 ppm except curex which was used in 50 ppm, 100 ppm and 200 ppm.

\section{In-vitro test}

The in-vitro test of different botanical extracts and fungicides against Bipolaris sorokiniana was done at the laboratory of NPPRC, Khumaltar, Lalitpur during 2019. Experiment was done in completely randomized design (CRD) by poisoned food technique (Schimitz, 1930). PDA media in lukewarm stage were amended with desired concentration of different botanical extracts and fungicides before pouring into $9 \mathrm{~cm}$ petri plates. PDA plates without botanical extract or fungicide were also used as control. Then, inoculation of $5 \mathrm{~mm}$ circular discs of pathogen (B. sorokiniana) (24 hrs. after pouring amended PDA media in petri plates) was done with help of sterile cork borer from one week old culture at the center of each PDA plates under aseptic condition. The experiment was done in three replications and the plates were incubated at $25^{\circ} \mathrm{C}$. Colony diameter i.e. radial mycelial growth of the fungus was recorded daily for one week by Vernier Caliper and percent growth inhibition (I \%) of B. sorokiniana was calculated by using the formula given by Vincent in 1947.

$\mathrm{I} \%=(\mathrm{C}-\mathrm{T}) / \mathrm{C} \times 100$

Where, $\mathrm{C}=$ Colony diameter in control plates (PDA only)

$\mathrm{T}=$ Colony diameter in treated plates (PDA with plant extracts or chemicals)

\section{Statistical analysis}

R Studio software using R-3.6.3 and the agricolae package ver. 1.3-3 was used for the analysis of variance (ANOVA) to test the significance of treatments effect on mycelial growth of $B$. sorokiniana. Duncan's multiple range test (DMRT) was done to compare the means of significant treatments at $1 \%$ level of significance.

\section{RESULTS}

The different botanical extracts at different concentrations inhibited the mycelial growth of $B$. sorokiniana significantly $(\mathrm{p}<0.01)$. The highest radial mycelial growth was observed in control and neem leaf extract $(9 \mathrm{~cm})$ at $5 \%$ concentration and second highest was in case of neem $(8.64$ $\mathrm{cm})$ at $10 \%$ which were statistically non-significant to control $(9 \mathrm{~cm})$ where other treatments were found significantly different with control. The lowest radial mycelial growth was observed in garlic extract $(4.24 \mathrm{~cm})$ at $15 \%$ concentration which was statistically at par to bojho extract $(4.28 \mathrm{~cm}$ and $4.47 \mathrm{~cm})$ at $15 \%$ and $10 \%$, and garlic extract $(4.67 \mathrm{~cm})$ at $10 \%$ concentration levels (Table 1).

All the tested botanical extracts showed control over the pathogen, B. sorokiniana growth in varying degrees except neem leaf extract at 5\% concentration (Table 1 and Figure 1). Garlic clove extract at $15 \%$ showed highest mycelial growth inhibition percentage $(52.85 \%)$ which was followed by bojho (52.48\% and $50.33 \%$ ) at $15 \%$ and $10 \%$, garlic $(48.07 \%)$ at $10 \%$ concentration and they were statistically similar to each other. The lowest inhibition percentage was observed in neem $(0 \%)$ at $5 \%$ concentration which was statistically different with all other treatment combinations. The mycelial growth inhibition percent of neem, garlic, eucalyptus, bojho and asuro at 15\% concentration level on PDA were 9.59\%, 52.85\%, 37.07\%, 52.48\% and $29.89 \%$ respectively (Table 1 ). From regression equation (Figure 3 ) between concentration of neem extract and mycelial growth inhibition percentage revealed that more than $99 \%$ of the variation in increased inhibition percentage could be explained by the increase in concentration followed by $87 \%$ of garlic, $79 \%$ of eucalyptus, $81 \%$ of bojho and $92 \%$ of asuro respectively. 
Table 1. Effect of different botanicals at different doses on radial mycelial growth and mycelial growth inhibition of $B$. Sorokiniana

\begin{tabular}{|c|c|c|c|}
\hline Botanicals & Concentration (\%) & Radial growth* $(\mathrm{cm})$ & Inhibition percentage* \\
\hline \multirow[t]{3}{*}{ Neem (Azadirachta indica) } & 5 & $9.00^{\mathrm{a}}$ & $0\left(0.00^{\mathrm{h}}\right)$ \\
\hline & 10 & $8.64^{\mathrm{ab}}$ & $4.04\left(1.59^{\mathrm{g}}\right)$ \\
\hline & 15 & $8.14^{\mathrm{b}}$ & $9.59\left(2.32^{f}\right)$ \\
\hline \multirow[t]{3}{*}{ Garlic (Allium sativum) } & 5 & $6.80^{\mathrm{cd}}$ & $24.44\left(3.23^{\mathrm{e}}\right)$ \\
\hline & 10 & $4.67^{f}$ & $48.07\left(3.89^{\mathrm{abc}}\right)$ \\
\hline & 15 & $4.24^{\mathrm{f}}$ & $52.85\left(3.99^{\mathrm{a}}\right)$ \\
\hline \multirow{3}{*}{$\begin{array}{l}\text { Eucalyptus (Eucalyptus } \\
\text { globolus) }\end{array}$} & 5 & $6.62^{\mathrm{cd}}$ & $26.41\left(3.30^{\mathrm{e}}\right)$ \\
\hline & 10 & $5.71^{\mathrm{e}}$ & $36.59\left(3.62^{\mathrm{cd}}\right)$ \\
\hline & 15 & $5.66^{\mathrm{e}}$ & $37.07\left(3.63^{\mathrm{bcd}}\right)$ \\
\hline \multirow[t]{3}{*}{ Bojho (Acorus calamus) } & 5 & $6.68^{\mathrm{cd}}$ & $25.74\left(3.28^{\mathrm{e}}\right)$ \\
\hline & 10 & $4.47^{\mathrm{f}}$ & $50.33\left(3.93^{\mathrm{ab}}\right)$ \\
\hline & 15 & $4.28^{f}$ & $52.48\left(3.97^{\mathrm{a}}\right)$ \\
\hline \multirow[t]{3}{*}{ Asuro (Justicia adhatoda) } & 5 & $7.05^{\mathrm{c}}$ & $21.63\left(3.11^{\mathrm{e}}\right)$ \\
\hline & 10 & $6.87^{\mathrm{cd}}$ & $23.70\left(3.19^{\mathrm{e}}\right)$ \\
\hline & 15 & $6.31^{\mathrm{de}}$ & $29.89\left(3.40 \mathrm{~d}^{\mathrm{e}}\right)$ \\
\hline Control (PDA only) & 0 & $9.00^{\mathrm{a}}$ & $0\left(0.00^{\mathrm{h}}\right)$ \\
\hline Grand mean & & 6.51 & 2.90 \\
\hline F-test & & $* * *$ & $* * *$ \\
\hline $\mathrm{LSD}(\leq 0.05)$ & & 0.7225 & 0.3061 \\
\hline $\mathrm{CV}(\%)$ & & 6.67 & 6.34 \\
\hline
\end{tabular}

*Values are means of three replications. Values in parentheses are log transformed values. Means followed by the same letter are not significantly different by DMRT $(P \leq 0.01)$. cm-centimeter, PDA-Potato Dextrose Agar, ***. highly significant.
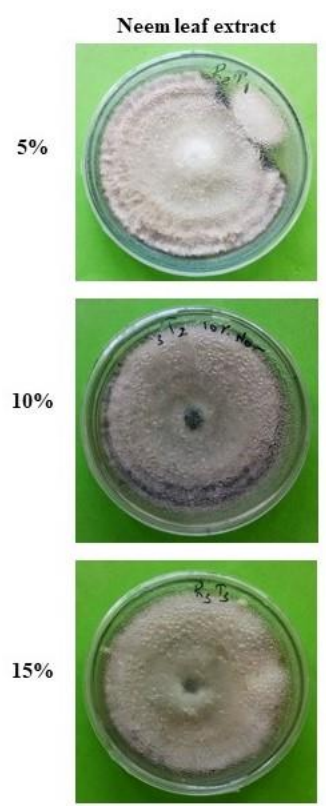
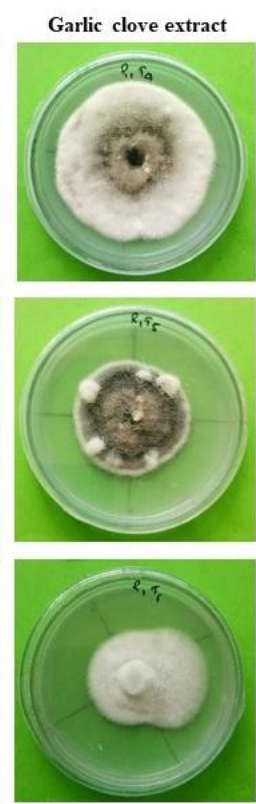
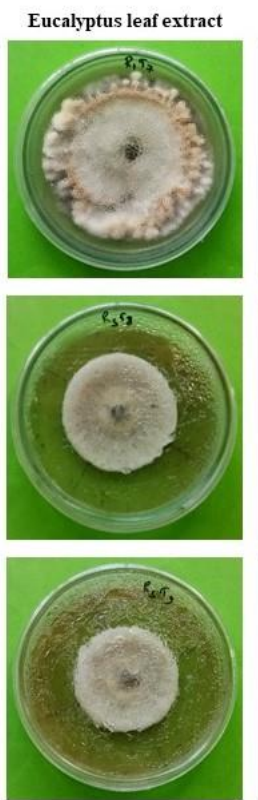
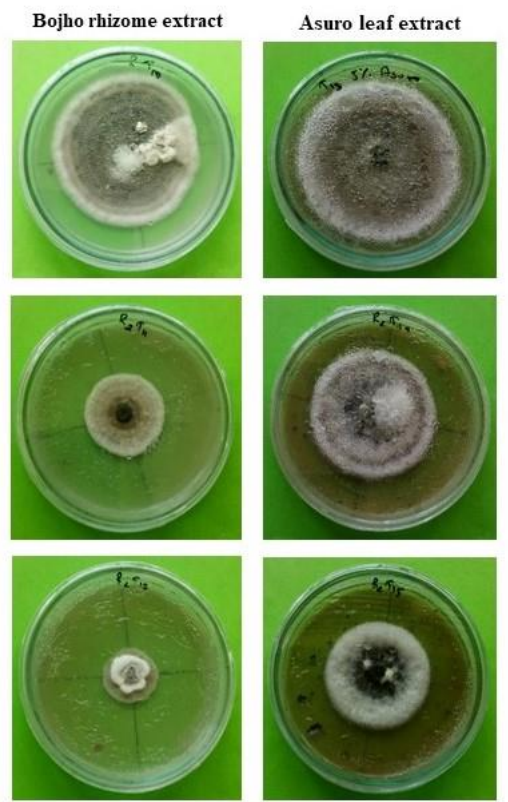

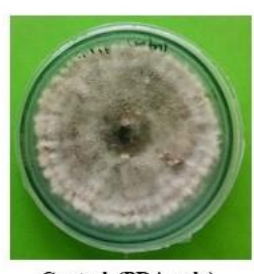

Control (PDA only)

Figure 1: Effect of different botanical extracts at different concentration on mycelial growth of B. sorokiniana

As compared to control, all the tested fungicides were found effective in controlling the growth of B. sorokiniana. The different fungicides at different concentrations inhibited the mycelial growth significantly $(\mathrm{p}<0.01)$. The highest radial mycelial growth was observed in control $(9$ $\mathrm{cm})$ which was statistically different with all other treatment combinations. The lowest radial mycelial growth was observed in tilt $(0 \mathrm{~cm})$ at all concentrations $(25 \mathrm{ppm}, 50 \mathrm{ppm}$ and 100 
Journal of Agriculture and Natural Resources (2020) 3(2): 296-305

ISSN: 2661-6270 (Print), ISSN: 2661-6289 (Online)

DOI: https://doi.org/10.3126/janr.v3i2.32534

ppm) followed by Sajha $(1.82 \mathrm{~cm})$ at $100 \mathrm{ppm}$, saaf $(2.38 \mathrm{~cm})$ at $100 \mathrm{ppm}$, sectin $(2.70 \mathrm{~cm})$ at $100 \mathrm{ppm}$ and so on (Table 2).

All the tested fungicides showed control over the pathogen, $B$. sorokiniana in varying degrees of difference with control. Tilt at all concentrations (25 ppm, $50 \mathrm{ppm}$ and $100 \mathrm{ppm}$ ) showed complete mycelial growth inhibition (100\%) which was followed by sajha $(79.78 \%)$ at 100 ppm, saaf $(73.59 \%)$ at $100 \mathrm{ppm}$, sectin $(70 \%)$ at $100 \mathrm{ppm}$ and so on. The lowest inhibition percentage was observed in bavistin $(8.74 \%)$ at $25 \mathrm{ppm}$ which was followed by criptan $(8 \%)$ at $25 \mathrm{ppm}$, bavistin $(15.19 \%)$ at $50 \mathrm{ppm}$, criptan $(22.11 \%)$ at $50 \mathrm{ppm}$ and bavistin $(23.56 \%)$ at $100 \mathrm{ppm}$. The mycelial growth inhibition percent of sectin, bavistin, vacomil plus, saaf, sajha, criptan and tilt at $100 \mathrm{ppm}$ concentration level on PDA were 70\%, 23.56\%, 53.78\%, 73.59\%, $79.78 \%, 37.22 \%$ and $100 \%$ respectively (Table 2 and Figure 2). From regression equation (Figure 4) between concentration of sectin and mycelial growth inhibition percentage revealed that more than $99 \%$ of the variation in increased inhibition percentage could be explained by the increase in concentration followed by $63 \%$ of curex, $98 \%$ of bavistin, $80 \%$ of vacomil plus, $98 \%$ of saaf, $95 \%$ of sajha and $97 \%$ of criptan respectively. But complete inhibition was found on tilt.

Table 2. Effect of different doses of fungicides on radial mycelial growth and mycelial growth inhibition of $B$. Sorokiniana

\begin{tabular}{|c|c|c|c|}
\hline Fungicides & Concentration (ppm) & Radial growth* $(\mathrm{cm})$ & Inhibition percentage* \\
\hline Sectin (Fenamidone $10 \%+$ & 25 & $4.62^{\text {fgh }}$ & $48.70^{\mathrm{ijk}}$ \\
\hline \multirow[t]{2}{*}{ Mancozeb 50\%) } & 50 & $3.87^{\mathrm{ij}}$ & $56.96^{\mathrm{gh}}$ \\
\hline & 100 & $2.70^{\mathrm{mn}}$ & $70.00^{\mathrm{cd}}$ \\
\hline Curex (Copper oxychloride & 50 & $5.08^{f}$ & $43.59^{k}$ \\
\hline \multirow[t]{2}{*}{$50 \%)$} & 100 & $3.51^{\mathrm{jk}}$ & $60.96^{\mathrm{fg}}$ \\
\hline & 200 & $3.39^{\mathrm{kl}}$ & $62.37^{\mathrm{ef}}$ \\
\hline \multirow[t]{3}{*}{ Bavistin (Carbendazim 50\%) } & 25 & $8.21^{\mathrm{b}}$ & $8.74^{\circ}$ \\
\hline & 50 & $7.63^{c}$ & $15.19^{\mathrm{n}}$ \\
\hline & 100 & $6.88^{\mathrm{d}}$ & $23.56^{\mathrm{m}}$ \\
\hline Vacomil plus (Metalaxyl 15\% + & 25 & $5.98^{\mathrm{e}}$ & $33.52^{1}$ \\
\hline \multirow[t]{2}{*}{ Copper oxychloride $35 \%$ ) } & 50 & $4.65^{\mathrm{fg}}$ & $48.37^{\mathrm{jk}}$ \\
\hline & 100 & $4.16^{\mathrm{hi}}$ & $53.78^{\mathrm{hi}}$ \\
\hline Saaf (Carbendazim 12\% + & 25 & $4.24^{\mathrm{ghi}}$ & $52.85^{\text {hij }}$ \\
\hline \multirow{2}{*}{ Mancozeb 63\%) } & 50 & $3.41^{\mathrm{jk}}$ & $62.15^{\mathrm{fg}}$ \\
\hline & 100 & $2.38^{\mathrm{n}}$ & $73.59^{\mathrm{c}}$ \\
\hline Sajha (Tebuconazole 10\% + & 25 & $4.13^{\mathrm{i}}$ & $54.07^{\mathrm{h}}$ \\
\hline \multirow[t]{2}{*}{ Sulphur $35 \%$ ) } & 50 & $2.91^{\mathrm{lm}}$ & $67.70^{\text {de }}$ \\
\hline & 100 & $1.82^{\circ}$ & $79.78^{\mathrm{b}}$ \\
\hline \multirow[t]{3}{*}{ Criptan (Captan 50\%) } & 25 & $8.28^{\mathrm{b}}$ & $8.00^{\circ}$ \\
\hline & 50 & $7.01^{\mathrm{d}}$ & $22.11^{\mathrm{m}}$ \\
\hline & 100 & $5.65^{\mathrm{e}}$ & $37.22^{1}$ \\
\hline \multirow[t]{3}{*}{ Tilt (Propiconazole 25\%) } & 25 & $0^{\mathrm{p}}$ & $100^{\mathrm{a}}$ \\
\hline & 50 & $0^{p}$ & $100^{\mathrm{a}}$ \\
\hline & 100 & $0^{\mathrm{p}}$ & $100^{\mathrm{a}}$ \\
\hline Control (PDA only) & 0 & $9.00^{\mathrm{a}}$ & $0^{\mathrm{p}}$ \\
\hline Grand mean & & 4.38 & 51.33 \\
\hline F-test & & $* * *$ & $* * *$ \\
\hline $\operatorname{LSD}(\leq 0.05)$ & & 0.48203 & 5.3559 \\
\hline $\mathrm{CV}(\%)$ & & 6.71 & 6.36 \\
\hline
\end{tabular}

*Values are means of three replications. Means followed by the same letter are not significantly different by

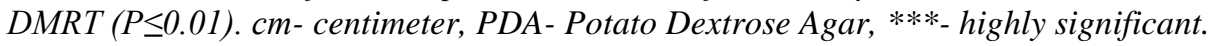


Journal of Agriculture and Natural Resources (2020) 3(2): 296-305

ISSN: 2661-6270 (Print), ISSN: 2661-6289 (Online)

DOI: https://doi.org/10.3126/janr.v3i2.32534

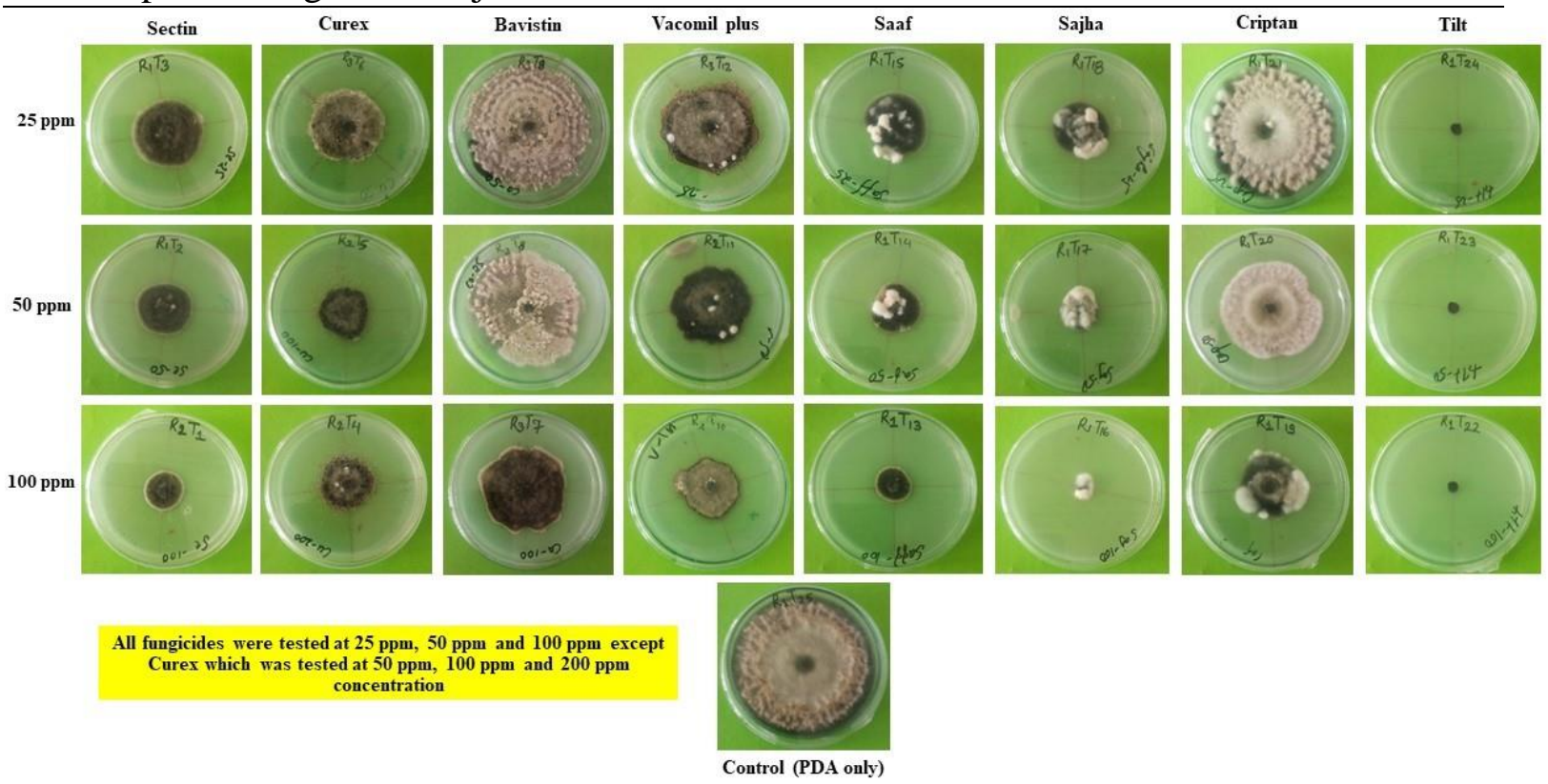

Figure 2: Effect of different fungicides at different concentration on mycelial growth of B. sorokiniana

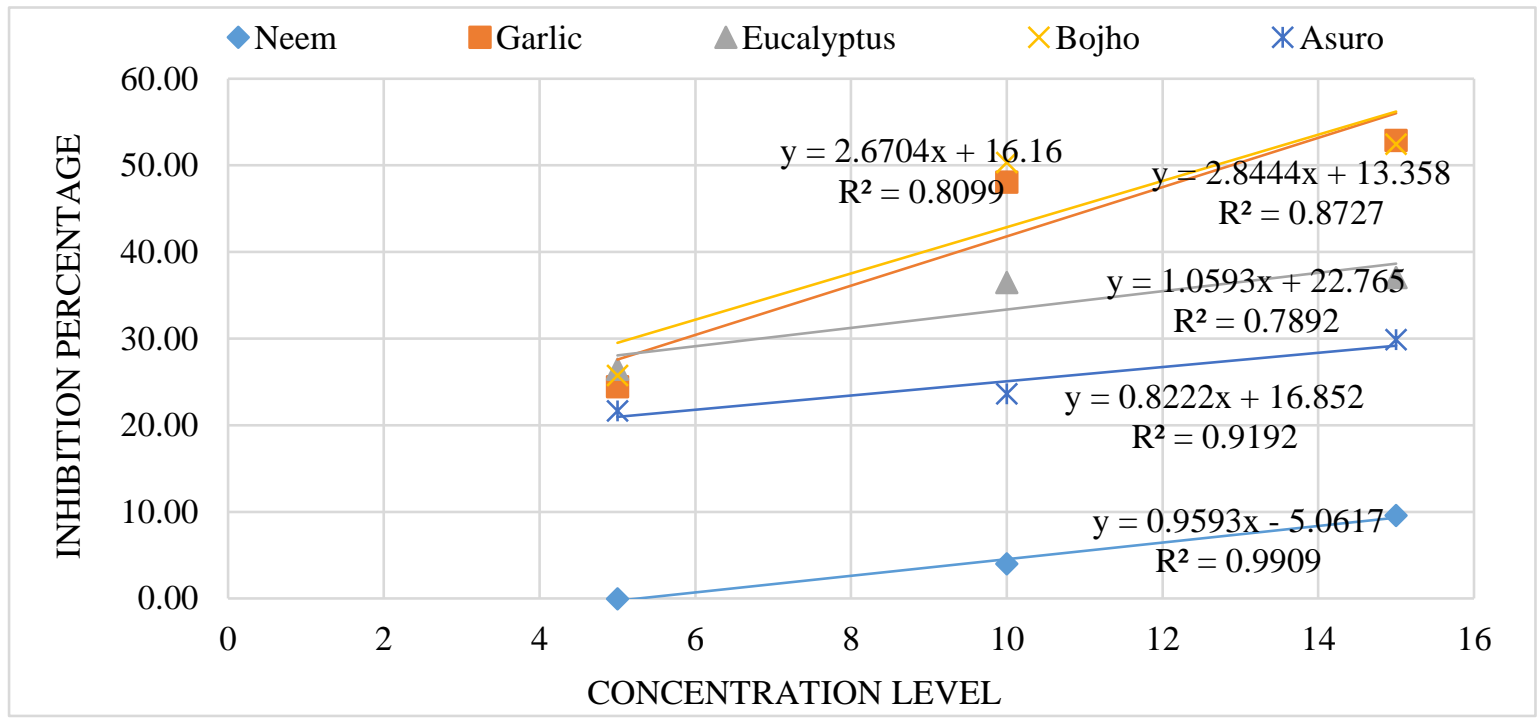

Figure 3: Functional relationship between concentration and mycelial growth inhibition percentage of botanical extracts on $B$. sorokiniana 


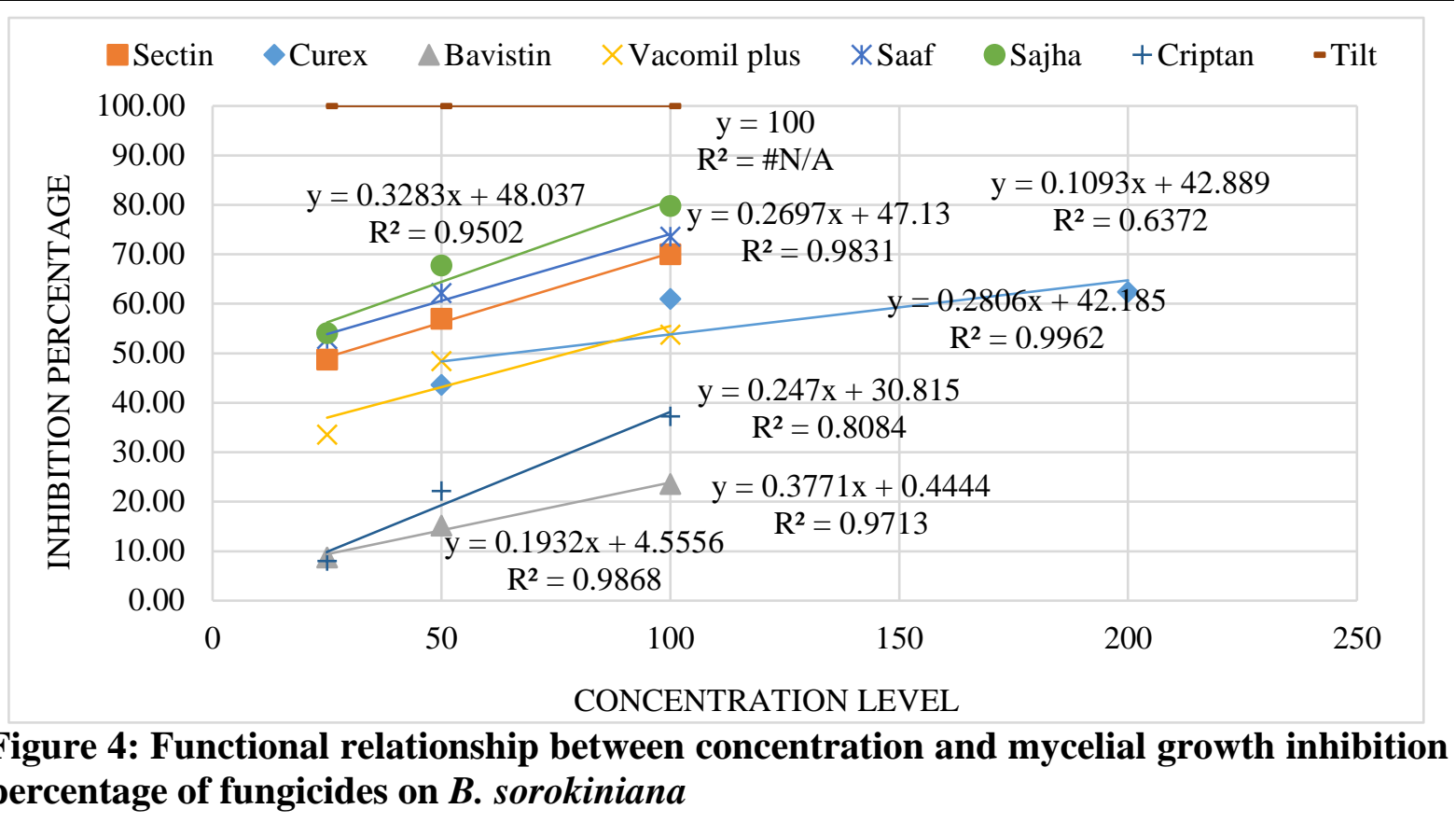

\section{DISCUSSION}

Due to the development of resistance by plant pathogens against many fungicides, a new and alternative fungi-toxic substance from different sources including botanicals need to be investigated. The results indicated that various plant extracts tested inhibited the mycelia growth of $B$. sorokiniana as compared to control. As the concentration of botanical extracts increases, the efficacy for controlling the mycelial growth of $B$. sorokiniana was also increased. Similar results on antifungal activity of different plant extracts has been reported by several workers (Hasan et al., 2012; Perello et al., 2013; Yasmin, 2016). At 15\% concentration, garlic clove extract significantly checked the growth of pathogen followed by bojho at $15 \%$ and $10 \%$, and garlic at $10 \%$. Many researchers found, extract of garlic bulbs were effective against $B$. sorokiniana (Miah et al., 1990; Khan and Fakir, 1995; Rahman et al., 1999; Ahmed et al., 2000; Hasan et al., 2005; Hoassain et al., 2005; Patidar, 2014). From the present study it can be concluded that garlic and bojho extract (both having more than 50\% mycelial growth inhibition) were effective botanicals in controlling the growth of B. sorokiniana. Hasan et al. (2012) studied the efficacy of different botanical extracts on B. sorokiniana by poison food technique under in-vitro condition and found that garlic extract at $15 \%$ concentration was superior to all other treatments with maximum mycelial growth inhibition of $67.5 \%$. Subedi et al. (2019) also reported that bojho (Acorus calamus) was the most effective botanical to suppress the growth of Exerohilum turcicum. Neem leaf extract was the least effective plant extract among the tested botanicals to inhibit the growth of B. sorokiniana while others gave at least more than $20 \%$ growth inhibition at all concentrations on PDA.

Among the tested fungicides, tilt (propiconazole 25\%) was the most effective (complete mycelial growth inhibition at all concentration) against the pathogen which was also supported by the finding of Hasan et al. (2012) who found propiconazole, hexaconazole and difenoconazole+propiconazole had complete inhibition on growth of B. sorokiniana. Kavita et al. (2017) evaluated fifteen fungicides in-vitro against $B$. sorokiniana of Barley and found that propiconazole at $0.1 \%$ and $0.05 \%$ was the most effective in controlling mycelial growth of pathogen. Several researchers also suggested foliar spray with triazoles fungicide for the effective management of foliar blight in wheat (Bhatta et al., 1997; Naitao and Yousan, 1997; 
Mahto, 1999). Even at $25 \mathrm{ppm}$, tilt has complete mycelial growth inhibition so it is better to check at even low concentration to find the minimum dose for controlling the pathogen. The bavistin (carbendazim 50\%) didn't inhibit the growth of pathogen and this was in agreement with the findings of Giri et al. (2001), Kavita et al. (2017) and Angdembe et al. (2019). In contrast to our findings, Samia et al. (2015) reported 100\% and $77 \%$ mycelial growth inhibition at $300 \mathrm{ppm}$ and $200 \mathrm{ppm}$ of bavistin respectively. So, there is some contradictions whether the fungicide carbendazim effect on the pathogen or not.

\section{CONCLUSION}

All the tested botanicals and fungicides exhibited fungicidal action and significantly inhibited mycelial growth of $B$. sorokiniana as compare to control under in-vitro. Also, based on the evaluation, it can be concluded that mycelial growth inhibition percentage increases with the increase in concentrations of all botanicals and chemical fungicides. In case of botanicals, the highest mycelial growth inhibition percentage was found by the application of garlic clove extract $(52.85 \%)$ at $15 \%$ which was followed by bojho $(52.48 \%)$ at $15 \%$ concentration while tilt $(100 \%)$ was the most effective fungicide which completely inhibits the mycelial growth of the pathogen at all concentrations. Also, fungicides viz. sajha, saaf and sectin had at least $70 \%$ mycelia growth inhibition at $100 \mathrm{ppm}$ concentration and were effective in controlling the pathogen. This findings needs further verification under in-vivo condition to see any phytotoxic effect on the host and find out the degree of control over the pathogen. Also, further investigation needs to be done along with other treatments combination to confirm the result and generate more information on controlling the pathogen.

\section{ACKNOWLEDGEMENTS}

Authors would like to acknowledge Nepal Agricultural Research Council (NARC), Government of Nepal for providing fund to conduct this experiment.

\section{Authors' Contributions}

P.B. Magar and S. Adhikary conceived and design the experiment. P.B. Magar and R. Koju collect the data. P.B. Magar analyzed the data and wrote the manuscript. S. Baidya revised the article for final approval of the version to be published.

\section{Conflicts of Interest}

The authors declare that they have no conflicts of interest.

\section{REFERENCES}

Ahmed, M.F., \& Islam, M.T. (2000). Efficacy of some fungicides and plant extracts against Bipolaris oryzae, M.S. Thesis. Department of Plant Pathology. Bangladesh Agricultural University, Mymensingh, 2000, 69.

Angdembe, B., Dhakal. N., G.C. S., Pant, K.R., \& Manandhar, H.K. (2019). In-vitro evaluation of commercially available fungicides against Bipolaris sorokiniana, the cause of spot blotch of Barley. Journal of Agriculture and Forestry University, 3, 105-111.

Bhandari, D., \& Tripathi, J. (2005). Intensity of Helminthosporium leaf blight of wheat in different methods of planting. Proceedings of $26^{\text {th }}$ National winter crops research workshop (pp 181-187). Nepal Agricultural Research Council held at Khumaltar, Kathmandu, Nepal.

Bhandari, D. (2017). Incursion of Helminthosporium leaf blight disease of wheat in comparatively cool hilly regions of Nepal. Journal of Medical Biomedical and Applied Sciences, $5,12$. 
Journal of Agriculture and Natural Resources (2020) 3(2): 296-305

ISSN: 2661-6270 (Print), ISSN: 2661-6289 (Online)

DOI: https://doi.org/10.3126/janr.v3i2.32534

Bhatta, M.R., Pokhrel, D.R., Devkota, R.N., Dubin, H.J., Mudvari, A., Bimb, H.P., Thapa, B.R., Sah, B.P., \& Bhandari, D. (1997). Breeding for resistance to Helminthosporium blight in Nepal: Strategies and genetic gains. In E. Duveiller, H.J. Dubin, J. Reeves \& A. McNab (Eds.), Helminthosporium blight of wheat: Spot blotch and tan spot (pp. 188-195). CIMMYT, Mexico.

Duveiller, E., Kandel, Y.R., Sharma, R.C., \& Shrestha, S.M. (2005). Epidemiology of foliar blights (spot blotch and tan spot) of wheat in the plains bordering the Himalayas. Phytopathology, 95, 248-256. DOI: https://doi.org/10.1094/PHYTO-95-0248

Giri, G.K., Gade, R.M., \& Patil, C.U. (2001). Seed borne Bipolaris sorokiniana in wheat and its chemical control. Journal of Soils and Crops, 11(1), 109-112.

Hasan, M.M., Ahmed, F., Islam, M.R., \& Murad, K.F.I. (2008). In-vitro effect of botanical extracts and fungicides against Bipolaris sorokiniana, causal agent of leaf blotch of barley. Journal of Agroforestry and Environment, 2(2), 9-13.

Hasan, M.M., Chowdhury, S.P., Alam, S., Hossain, B., \& Alam, M.S. (2005). Antifungal effects of plant extracts of seed-borne fungi of wheat seed regarding seed germination, seedling health and vigour index. Pakistan Journal of Biological Sciences, 8(9), 12841289. DOI: https://doi.org/10.3923/pjbs.2005.1284.1289

Hoassain, M.M., Khalequzzaman, K.M., Aminuzzaman, F.M., Mollah, M.R.A., \& Rahman, G.M.M. (2005). Effect of plant extracts on the incidence of seed-borne fungi of wheat. Journal of Agriculture and Rural Development, 3(1\&2), 39-43.

Kavita, Pande, S.K., Yadav, J.K. \& Dalbeer. (2017). In vitro Evaluation of Fungicides against Bipolaris sorokiniana causing spot blotch of barley (Hordeum vulgare L.). International Journal of Current Microbiology and Applied Sciences, 6(10), 47344739. DOI: https://doi.org/10.20546/ijcmas.2017.610.439

Khan, A.A., \& Fakir, G.A. (1995). Seed treatment with garlic extract to control seed-borne pathogens of jute. Bangladesh Journal Plant Pathology, 11, 1-2.

Kumar, J., Schafer, P., Hückelhoven, R., Langen, G., Baltruschat, H., Stein, E., Nagarajan, S., \& Kogel, K. (2002). Bipolaris sorokiniana, a cereal pathogen of global concern: cytological and molecular approaches towards better control. Mol. Plant Pathol, 3(4), 185-195. DOI: https://doi.org/10.1046/j.1364-3703.2002.00120.x

Mahto, B.N. (1999). Management of Helminthosporium leaf blight of wheat in Nepal. Indian Phytopathology, 52(4), 408-413.

Miah, A.T., Ahmed, M.U., Sharma, N.R., Ali, A., \& Miah, S.A. (1990). Antifungal activity of some plant extract. Bangladesh Journal of Botany, 19(1), 5-10.

MoALD. (2018/19). Statistical information on Nepalese Agriculture 2075/76 (2018/19). Planning and Development Cooperation Coordination Division. Ministry of Agriculture and Livestock Development. Government of Nepal. Singhadurbar, Kathmandu, Nepal.

Naitao, C., \& Yousan, W. (1997). Incidence and current management of spot blotch of wheat in china. In E. Duveiller, H.J. Dubin, J. Reeves \& A. McNab (Eds.), Helminthosporium blight of wheat: Spot blotch and tan spot (pp. 119-125). CIMMYT, Mexico.

Pasquer, F., Isidore, E., Zarn, J., \& Keller, B. (2005). Specific patterns of changes in wheat gene expression after treatment with three antifungal compounds. Plant Molecular Biology, 57, 693-707. DOI: https://doi.org/10.1007/s11103-005-1728-y

Patidar, S. (2014). Studies on Bipolaris sorokiniana (Sacc.) Shoemaker causing leaf blight of wheat. [M. Sc. (Agri.) dissertation, Rajmata Vijayaraje Scinda Krishi Vishwa Vidyalaya].

Perello, A., Ulrike, N., \& Slusarenko, A.J. (2013). In vitro efficacy of garlic extract to control fungal pathogens of wheat. Journal of Medicinal Plants Research, 7(24), 1809-1817. DOI: https://doi.org/10.5897/JMPR12.511 
Rahman, G.M.M., Islam, M.R., \& Wadud, M.A. (1999). Seed treatment with plant extracts and hot water: A potential biophysical method of controlling seed borne infection of wheat. Bangladesh Journal of Training Development, 12(1-2), 185-190.

Regmi, A.P., Ladha, J.K., Pasuquin, E.M., Pathak, H., Hobbs, P.R., Shrestha, L.L., Gharti, D.B., \& Duveiller, E. (2002). The role of potassium in sustaining yields in a long-term rice-wheat experiment in the Indo-Gangetic plains of Nepal. Biology and Fertility of Soils, 36,240-247. DOI: https://doi.org/10.1007/s00374-002-0525-x

Ruckstuhl, M. (1997). Bipolaris sorokiniana: Studies on its epidemiology and population structure in the rice-wheat cropping pattern of Nepal. In E. Duveiller, H.J. Dubin, J. Reeves \& A. McNab (Eds.), Helminthosporium blight of wheat: Spot blotch and tan spot (pp. 88-106). CIMMYT, Mexico.

Samia, T., Sultana, S., Adhikary, S.K., \& Quddus, K.G. (2015). Effect of fungicides against Bipolaris sorokiniana isolates collected from different wheat growing regions of Bangladesh. Mycopath, 13(2), 81-88.

Schimitz, H. (1930). A suggested toximetric method for wood preservatives. Industrial \& Engineering Chemistry Analytical Edition, 2(4), 361-363. DOI: https://doi.org/10.1021/ac50072a004

Sharma, R.C., \& Duveiller, E. (2006). Spot blotch continues to cause substantial grain yield reductions under resource limited farming conditions. Journal of Phytopathology, 154(7-8), 482-488. DOI: https://doi.org/10.1111/j.1439-0434.2006.01134.x

Subedi, S., Neupane, S., BK, S., \& Oli, L. (2019). In-vitro evaluation of botanicals, fungi-toxic chemicals and bio-control agent for efficacy against turcicum leaf blight of maize. Journal of Nepal Agricultural Research Council, 5, 73-80. DOI: https://doi.org/10.3126/jnarc.v5i1.23811

Vincent, J.M. (1947). Distortion of fungal hyphae in the presence of certain inhibitors. Nature, 159, 850. DOI: https://doi.org/10.1038/159850b0

Yasmin, S. (2016). In-vitro evaluation of botanical extracts against some soil and seed borne fungi of economic importance. Journal of Agriculture and Ecology Research International, 8(2), 1-11. DOI: https://doi.org/10.9734/JAERI/2016/26222 